\title{
Pendidikan Berbasis Masyarakat dan Penerapannya Pada Madrasah Aliyah Al-Ma'arif Bilae Kabupaten Bone
}

\author{
Sultan Hasanuddin $1 *$ \\ ${ }^{1}$ Program Studi Pendidikan Agama Islam, Institut Agama Islam Negeri Bone, Jl. HOS. Cokroaminoto, \\ Kabupaten Bone, Sulawesi Selatan, Indonesia. \\ * Korespondensi Penulis. E-mail: sultanhasanuddin838509@gmail.com
}

\begin{abstract}
Abstrak
Penelitian ini bertujuan untuk mengetahui penerapan pendidikan berbasis masyarakat pada Madrasah Aliyah Al-Ma'arif Bilae Kabupaten Bone. Penelitian ini membahas tentang penerapan pendidikan berbasis masyarakat, faktor yang menjadi pendukung dan penghambat penerapan pendidikan berbasis masyarakat pada Madrasah Aliyah Al-Ma'arif Bilae kabupaten Bone serta solusinya. Metode pengumpulan data yaitu observasi, wawancara dan studi dokumentasi. Data yang telah terkumpul kemudian diolah dengan teknik analisis deskriptif kuantitatif. Pengolahan data melalui tiga tahap, yaitu reduksi data, penyajian data dan penarikan kesimpulan. Hasil penelitian menunjukkan bahwa keterlibatan masyarakat hanya sebatas pada penyediaan saran dan prasaran. Faktor yang menjadi pendukung pada pendidikan berbasis masyarakat Madrasah Aliyah Bilae kabupaten Bone yaitu masyarakat, pemerintah serta sarana dan prasaran karena masyarakat merasa memiliki madrasah tersebut sehingga dengan sukarela menyediakan sarana dan prasarana serta dukungan dari pemerintah. Faktor yang menjadi penghambat adalah belum maksimalnya perencanaan pendidikan berbasis masyarakat serta kurangnya anggaran dalam proses pengelolaannya. Sehingga dibutuhkan perencanaan yang matang dalam proses pendidikan serta sumber anggarannya tidak berpusat pada bantuan pemerintah akan tetapi adanya keterlibatan masyarakat.
\end{abstract}

Kata Kunci: Madrasah Aliyah, Pendidikan Berbasis Masyarakat

\section{Community Based Education and Its Application to Al-Ma'arif Aliyah Madrasah Bilae Bone Regency}

\begin{abstract}
This study aims to determine the application of community-based education at Al-Ma'arif Aliyah Madrasah Bilae Bone Regency. This study discusses the application of community-based education, the factors that become supporters and inhibitors of the application of community-based education to the Aliyah Al-Ma'arif Madrasah in Bone district and the solution. Methods of data collection are observation, interview and documentation study. The collected data is then processed with quantitative descriptive analysis techniques. Processing data through three stages, namely data reduction, data presentation and conclusion drawing. The results of the study indicate that community involvement is only limited to providing advice and infrastructure. Factors that become supporters of community-based education Aliyah Madrasah If Bone regency is the community, the government and facilities and infrastructure because the community feels that they have the madrasa so that they voluntarily provide facilities and infrastructure and support from the government. The factor that becomes an obstacle is not yet the maximum community-based education planning and lack of budget in the management process. So that careful planning is needed in the education process and the source of the budget is not centered on government assistance but the involvement of the community.
\end{abstract}

Keywords: Aliyah Madrasah, Community Based Education 


\section{PENDAHULUAN}

Pendidikan merupakan salah satu faktor yang sangat dominan dan menetukan kualitas kehidupan manusia dan kemajuan suatu bangsa. ${ }^{1}$ Oleh karena itu, sudah selayaknya apabila masyarakat dan pemerintah memiliki komitmen yang kuat dan bersama-sama mengupayakan penyelenggaraan pendidikan yang bermutu sehingga mampu mencetak sumber daya manusia yang beriman dan bertakwa kepada Tuhan Yang Maha Esa, memiliki kecerdasan intelektual, emosional dan spiritual didukung dengan keterampilan dan etos kerja yang tinggi. Upaya untuk merumuskan kebijakan penyelenggara pendidikan yang merata, bermutu, epektif dan efisien merupakan tanggung jawab bersama antara orang tua peserta didik, pemerintah, dunia usaha serta masyarakat secara umum yang ikut serta secara aktif untuk menciptakan situasi yang kondusif untuk mendukung proses penyelenggara pendidikan tersebut. ${ }^{2}$

Dalam dunia pendidikan dikenal adanya jalur pendidikan formal (sekolah), nonformal (masyarakat/luar sekolah), dan informal (keluarga). Ketiga jalur ini oleh Ki Hadjar Dewantara dikenal dengan Tri Pusat Pendidikan, karena ketiganya memberikan andil yang besar bagi proses pengembangan manusia untuk mencapai kehidupan dalam berbagai dimensi. ${ }^{3}$ Sebagai lembaga pendidikan, kebermaknaan sekolah semestinya dapat dirasakan oleh peserta didik dan masyarakat. ${ }^{4}$ Peserta didik adalah pihak yang secara langsung memperoleh pengetahuan, keterampilan serta nilai dan sikap yang diajarkan di sekolah. Apa yang didapat tersebut semestinya memiliki nilai fungsi bagi dirinya sebagai pribadi yang memiliki kematangan mental, moran dan intelektual serta kemampuan untuk memiliki kematangan hidup, sebagai anggota masyarakat yang memiliki peran dan fungsi tersendiri, serta sebagai warga Negara yang sadar akan hak dan kewajibannya. Selain itu, dari dimensi masyarakat sekolah sudah tentu diharapakan sebagai media transfer kebudayaan sekaligus sebagai agen pembaharu atau transformasinya.

Apabila kita cermati lebih lanjut mulai dari masyarakat dan kebudayaan yang sederhana, maka lembaga pendidikan meliputi: (1) keluarga atau rumah tangga orang tua, sebagai wujud kehidupan sosial yang asasi sebagai unit kehidupan bersama manusia kecil, keluarga adalah lembaga kehidupan yang asasi dan alamiah yang pasti secara alamiah dialami oleh kehidupan seorang manusia; dan (2) masyarakat, yakni lingkungan sosial yang ada disekitar keluarga, baik itu kampung, desa ataupun pulau. ${ }^{5}$ Kedua bentuk lembaga tersebut kemudian mengalami perkembangan sesuai dengan kemajuan kebudayaan manusia. Kemudian kita mengenal susunan atau struktur kelembagaan yang ada disekitar masyarakat dan kebudayaan dewasa ini. Artinya masyarakat yang lebih maju memiliki tata susunan kelembagaan yang lebih rumit (kompleks), karena masyarakat dan kebudayaan yang lebih maju itu mengadakan pembagian tugas atau tanggung jawab fungsi-fungsi kehidupan.

Lebih lanjut dikatakan bahwa pendidikan formal dewasa ini menghadapi krisis yang ditunjukkan dengan gejala antara lain: ketidak cocokan antara kurikulum dengan perkembangan ilmu pengetahuan dan kebutuhan nyata peserta didik, ketidak sesuaian antara pendidikan dengan perkembangan kebutuhan masyarakat, ketidak seimbangan yang terus menerus antara pendidikan dan dunia kerja, ketidak mampuan lembaga pendidikan formal dalam memberikan kesempatan pemerataan pendidikan bagi semua kelompok masyarakat, dan meningkatnya biaya penyelenggara pendidikan formal yang tidak diimbangi oleh kemampuan Negara terutama Negara berkembang untuk membiayainya. ${ }^{6}$

Dari uraian sebagai mana penulis utarakan di atas, tergambar bahwa ada lima hal pokok yang sangat penting yang dapat dan harus dijadikan pedoman untuk kegiatan belajar mengajar khususnya

\footnotetext{
${ }^{1}$ Sultan Hasanuddin, "Pembinaan Mahasiswa Prodi Pendidikan Agama Islam Yang Aktif Pada Organisasi Mahasiswa Iain Bone,” Ekspose: Jurnal Penelitian Hukum Dan Pendidikan 17, no. 1 (2019): 539-48.

2 Erlan Muliadi, "Urgensi Pembelajaran Pendidikan Agama Islam Berbasis Multikultural Di Sekolah," Jurnal Pendidikan Islam 1, no. 1 (2012): 55-68.

${ }^{3}$ Rhamat Hidayat, "Pendidikan Berbasis Masyarakat," Jurnal Attarbiya 1, no. 1 (2004): 184.

4 Umberto Sihombing, "Menuju Pendidikan Bermakna Melalui Pendidikan Berbasis Masyarakat," Jakarta: CV Multiguna, 2002.

5 Ida Rochmawati, "Optimalisasi Peran Madrasah Dalam Pengembangan Sistem Nilai Masyarakat," PEDAGOGIA: Jurnal Pendidikan 1, no. 2 (2012): 161-72.

${ }^{6}$ Djudju Sudjana, "Pendidikan Nonformal: Wawasan, Sejarah Perkembangan, Filsafat, Teori Pendukung, Asas," Bandung: Falah Production, 2004.
} 
dalam pendidkan formal agar berhasil sesuai dengan yang diharapkan, yaitu pesifikasi hasil belajar mengajar yang dilakukan, memilih cara pendekatan belajar mengajar yang dianggap paling tetap dan efektif untuk mencapai sasaran, memilih dan menetapkan prosedur, menerapkan norma-norma atau kriteria keberhasilan sehingga guru mempunyai pegangan yang dapat dijadikan ukuran untuk menilai sejauh mana keberhasilan tugas-tugas yang telah dilakukannya, dan masalah pokok yang menjadi pedoman dalam pelaksanaan proses belajar mengajar tersebut tidak terlepas dari kegiatan pembelajaran.

Kalau pelaksanaan pendidikan disekolah sudah melaksanakan kelima hal pokok tersebut di atas, maka secara tidak langsung sekolah sudah memainkan pengaruh yang nyata dalam kehidupan masyarakat. Pengaruh tersebut antara lain: mencerdaskan kehidupan masyarakat, membawa virus perubahan bagi perkembangan masyarakat, melahirkan warga masyarakat yang siap dan terbekali bagi kepentingan kerja di lingkungan masyarakat, dan melahirkan sikap positif dan konstruktif bagi warga masyarakat, sehingga tercipta integrasi sosial yang harmonis di tengah-tengah masyarakat.

Orientasi tersebut senantiasa menjadi perhatian dari lembaga-lembaga pendidikan formal. Hal ini berkaitan dengan falsafah hidup suatu bangsa atau masyarakat dan sudah tentu mendambakan keharmonisan dan keutuhan sosial dari kehidupan berbangsa dan bernegara. Tata etika di dalam hidup bermasyarakat dan bernegara hak dan kewajiban selaku warga Negara. Dalam kenyataannya hal tersebut selalu terintegrasi di dalam kurikulum pendidikan baik di sekolah dasar, lanjutan, ataupun perguruan tinggi.

Akan tetapi dalam penerapan falsafah tersebut juga harus ditopang dengan keterlibatan unsur yang memegang peranan penting yaitu masyarakat. Hal ini diperkuat dalam Undang-undang Republik Indonesia no 20 tahun 2003 tentang sistem pendidikan nasional, tentang peran serta masyarakat dalam pendidikan yang tertuang pada pasal 54 ayat (1) Peran serta masyarakat dalam pendidikan meliputi peran serta perorangan, kelompok, keluarga, organisasi profisi, pengusaha dan organisasi kemasyarakatan dalam menyelenggarakan dan pengendalian mutu pada satuan pendidikan. Ayat (2) masyarakat dapat berperan serta sebagai sumber pelaksanaan dan pengguna hasil pendidikan. ${ }^{7}$

Demikian pula pendidikan berbasis masyarakat sebagaimana yang tertuang pada pasal 55 ayat (1) masyarakat berhak menyelenggarakan pendidikan berbasis masyarakat pada pendidikan formal dan non formal sesuai dengan kekhasan agama, lingkungan sosial dan budaya untuk kepentingan masyarakat, ayat (2) penyelenggaraan pendidikan berbasis masyarakat mengembangkan dan melaksanakan kurikulum dan evaluasi pendidikan, serta manajemen dan pendanaannya sesuai dengan standard nasional pendidikan. Ayat (3) Dana penyelenggaraan pendidikan berbasis masyarakat dapat bersumber dari penyelenggaraan, masyarakat, pemerintah, pemerintah daerah dan / atau sumber lain yang tidak bertentangan dengan peraturan perundang-undangan yang berlaku; ayat (4) lembaga pendidikan berbasis masyarakat dapat memperoleh bantuan tekhnis, subsidi dana dan sumber daya lain secara adil dan merata dari pemerintah dan atau pemerintah daerah. ${ }^{8}$

Berdasarkan penjelasan di atas, maka tujuan dari tulisan ini adalah untuk mengetahui penerapan pendidikan berbasis masyarakat pada Madrasah Aliyah Al-Ma'arif Kabupaten Bone dan untuk mengetahui Faktor pendukung dan penghambat dalam penerapan pendidikan berbasis masyarakat pada Madrasah Aliyah Al-Ma'arif Kabupaten Bone serta solusianya.

\section{METODE}

Penelitian ini adalah penelitian lapangan dengan menggunakan metode kualitatif. Metode kualitatif adalah metode penelitian yang berlandaskan pada filsafat postpositivisme, digunakan untuk meneliti kondisi obyek yang alamiah (sebagai lawannya adalah eksprimen) dimana peneliti adalah sebagai instrumen kunci, pengambilan sampel sumber data dilakukan secara purposive dan snowboal, teknik pengambilan data trianggulasi (gabungan), analisis data bersifat induktif/kualitatif, dan hasil penelitian kualitatif lebih menekankan makna dari pada generalisasi. ${ }^{9}$

\footnotetext{
7 Presiden Republik Indonesia, "Undang-Undang Republik Indonesia Nomor 20 Tahun 2003 Tentang Sistem Pendidikan Nasional,” Pub. L. No. 20, 79 (2003).

${ }^{8}$ Indonesia.

${ }^{9}$ Sugiyono, Metode Penelitian Pendidikan:(Pendekatan Kuantitatif, Kualitatif Dan $R \&$ D) (Alfabeta, 2008).
} 
Dalam menemukan kebenaran terhadap masalah yang dikemukakan, maka untuk memperoleh data yang akurat ditempuh dua cara, yaitu library research (penelitian kepustakaan) dan field research. Library research, mengumpulkan dan membaca buku-buku yang ada kaitannya dengan masalah yang akan dibahas serta mengutip beberapa buku tentang metode pembelajaran yang berkaitan dengan kajian tersebut. ${ }^{10}$ Field research (penelitian lapangan), turun ke lokasi penelitian untuk memperoleh data-data konkrit mengenai masalah yang akan dibahas melalui observasi, interview dan dokumentasi. ${ }^{11}$

Data yang telah terkumpul kemudian diolah dengan teknik analisis deskriptif kuantitatif. Pengolahan data melalui tiga tahap, yaitu reduksi data, penyajian data dan penarikan kesimpulan.

\section{PEMBAHASAN}

\section{Penerapan pendidikan berbasis masyarakat pada Madrasah Aliyah Al-Ma'arif Kabupaten Bone.}

Pendidikan Berbasiskan Masyarakat (Community Based Education) intinya adalah bahwa masyarakat yang menentukan kebijakan serta ikut berpartisipasi dalam menentukan pendidikan yang bermutu bagi generasi dimasa yang akan datang. ${ }^{12}$ Dalam pengertian ini, masyarakat tidak semestinya menyerahkan seluruh pendidikan anak-anak mereka kepada sekolah semata-mata, tetapi ikut memikirkan serta bertanggungjawab bersama kalangan pendidikan akan berhasilnya pendidikan anakanak mereka. Dengan demikian, diharapkan akan tercipta hubungan yang harmonis di antara pendidikan di rumah dan pendidikan di sekolah serta pendidikan di luar sekolah.

Pendidikan Berbasis Masyarakat merupakan perwujudan demokratisasi pendidikan melalui perluasan pelayanan pendidikan untuk kepentingan masyarakat. ${ }^{13}$ Pendidikan berbasis masyarakat menjadi sebuah gerakan penyadaran masyarakat untuk terus belajar sepanjang hayat dalam mengisi tantangan kehidupan yang berubah-ubah. Secara konseptual, pendidikan berbasis masyarakat adalah model penyelenggaraan pendidikan yang bertumpu pada filosofi "dari masyarakat, oleh masyarakat dan untuk masyarakat". ${ }^{14}$ Pendidikan dari masyarakat artinya pendidikan memberikan jawaban atas kebutuhan masyarakat, ia muncul karena adanya inisiatif masyarakat sendiri dengan penuh kesadara. Pendidikan oleh masyarakat artinya masyarakat ditempatkan sebagai subyek/pelaku pendidikan, bukan objek pendidikan.

Pada konteks ini, masyarakat dituntut peran dan partisipasi aktifnya dalam setiap program pendidikan serta bertanggung jawab dengan semangat kemandirian. Adapun pengertian pendidikan untuk masyarakat artinya masyarakat diikutsertakan dalam semua program yang dirancang untuk menjawab kebutuhan mereka, demi kemajuan kehidupan bersama. ${ }^{15}$ Secara singkat dikatakan, masyarakat perlu diberdayakan, diberi peluang dan kebebasan untuk mendesain, merencanakan, membiayai, mengelola dan menilai sendiri apa yang diperlukan secara spesifik untuk masyarakat.

Berdasar pada konsep di atas, maka pendidikan berbasis masyarakat menitik beratkan pada keterlibatan berbagai unsur dalam rangka penerapannya. Terkhusus pada Madrasah Aliyah Al-Ma'arif Bilae Kabupaten Bone penerapan pendidikan berbasis masyarakat dapat dilihat dalam berbagai hal, yakni keberadaan Madrasah Aliyah Al- Ma'arif atas inisiatif masyarakat setempat, madrasah swasta di naungi oleh yayasan yang acap kali berkultur sangat kaku dan cenderung otoriter, dan pengelola madrasah kurang memahami secara mendalam dan luas peran serta fungsi mereka.

Pertama, keberadaan Madrasah Aliyah Al- Ma'arif atas inisiatif masyarakat setempat, sehingga dalam proses pengadaan sarana dan prasarana tidak membebankan pihak lain. Hal ini dibuktikan dengan

\footnotetext{
${ }^{10}$ Sugiyono.

11 Yatim Riyanto, Metodologi Penelitian Pendidikan Kualitatif dan Kuantitatif (Surabaya: Unesa university press, 2007).

12 Toto Suharto, Pendidikan Berbasis Masyarakat; Relasi Negara Dan Masyarakat Dalam Pendidikan (LKIS Pelangi Aksara, 2012).

13 Yadi Ruyadi, "Model Pendidikan Karakter Berbasis Kearifan Budaya Lokal: Penelitian Terhadap Masyarakat Adat Kampung Benda Kerep, Cirebon, Provinsi Jawa Barat Untuk Pengembangan Pendidikan Karakter di Sekolah," in Proceedings of The 4th International Conference on Teacher Education, 2010, 577-95.

${ }^{14}$ Suharto, Pendidikan Berbasis Masyarakat; Relasi Negara Dan Masyarakat Dalam Pendidikan.

${ }^{15}$ Nurhattati Fuad, "Manajemen Pendidikan Berbasis Masyarakat: Konsep Dan Strategi Implementasi," Jakarta: Raja Grafindo Persada, 2014.
} 
kerelaannya mewakafkan tanahnya untuk dijadikan lokasi sekolah, begitu juga dalam proses pembangunan gedung awalnya mereka lakukan dalam bentuk swadaya masyarakat dan dikerjakan dengan gotong-royong.

Kedua, biasanya madrasah terutama madrasah swasta di naungi oleh yayasan yang acap kali berkultur sangat kaku dan cenderung otoriter. Yayasan berlaku sebagai pemegang otoritas dalam pengelolaan madrasah dalam arti yang luas. Akan tetapi di Madrasah Aliyah Al- Ma'arif konsep tersebut tidak diberlakukan dengan memberikan kepercayaan secara langsung kepada masyarakat untuk pengelolaannya. Walaupun dalam struktur kepengurusan yayasan tetap ada akan tetapi proses pengambilan keputusan yang sangat urgen terhadap madrasah dilakukan secara mufakat.

Ketiga, awalnya pengelola madrasah kurang memahami secara mendalam dan luas peran serta fungsi mereka. Mereka belum faham sejauh mana tugas dari yayasan dan tugas dari pengelola madrasah. Untuk mengatasi hal yang demikian, pengurus melakukan konsultasi keberbagai pihak yang sudah punya pengalaman dalam hal ini. Sehingga sangat jelas bahwa mau tidak mau keterlibatan masyarakat menjadi hal yang tidak dapat di nafikan, bahkan keterlibatan mereka menjadi sangat penting demi kemajuan sekolah. Karena peran masyarakat sangat penting dalam pendidikan.

Berdasar pada penjelasan di atas, dapat dipahami bahwa keterlibatan masyarakat dalam pengelolaan madrasah kaitannya dengan penerapan pendidikan berbasis masyarakat pada Madrasah Aliyah Al-Ma'arif Bilae Kabupaten Bone hanya pada penyediaan sarana dan prasarana. Masyarakat belum masuk pada sistem pengelolaan Madrasah dalam hal ini penyusunan kurikulum.

\section{Faktor Pendukung dan Penghambat Penerapan Pendidikan Berbasis Masyarakat pada Madrasah Aliyah Al-Ma'arif Bilae Kabupaten Bone serta Solusinya}

Implementasi program pendidikan harus didukung oleh berbagai pihak dalam rangka mencapai tujuan dari pendidikan yaitu mencerdaskan kehidupan bangsa. Proses pencerdasan dapat dilakukan dalam lembaga pendidikan baik yang formal maupun nonformal. ${ }^{16}$ Akan tetapi dalam penerapannya tidak terlepas dari peran berbagai pihak yang harus menjadi pendukung dalam pelaksanaan pendidikan tersebut. Begitu pula dengan Madrasah Aliyah Al-Ma'arif Bilae kabupaten Bone, dalam pelaksanaan pendidikan berbasis masyarakat mendapat dukungan dari berbagai pihak yaitu masyarakat, pemerintah serta sarana dan prasarana.

\section{Masyarakat}

Masyarakat memiliki kesempatan yang seluas-luasnya untuk berpartisipasi dalam penyelenggaraan pendidikan. ${ }^{17}$ Dalam penyelenggaraan pendidikan formal masyarakat mempunyai peranan penting dalam rangka peningkatan kualitas sumber daya manusia serta melengkapi keberadaan dan fungsi pendidikan. Pendidikan non formal menyesuaikan diri dengan kebutuhan masyarakat dan tuntutan dunia usaha/industri. Pendidikan formal memerlukan pengelolaan atau manajemen yang baik, Oleh karena itu, pendidikan harus dapat dipertanggungjawabkan kepada masyarakat.

Penerapan pendidikan berbasis masyarakat pada Madrasah Aliyah Al-Ma'arif Bilae Kabupaten Bone sangat didukung oleh masyarakat sekitar. Hal ini terbukti dengan antusiasme masyarakat dengan keberadaan madrasah tersebut sehingga mewakafkan tanahnya untuk dijadikan sebagai tempat untuk mendirikan madrasah. Selain itu mereka juga melakukan gotong royong dalam mendirikan gedung madrsah sebagai tempat siswa untuk melakukan proses belajar mengajar.

\section{Pemerintah}

Dalam mengembangkan pendidikan berbasis masyarakat seharusnya pemerintah memberikan pelayanan terbaik bagi masyarakat. Melayani masyarakat, merupakan pilar utama dalam memberdayakan dan membantu masyarakat dalam menemukan kekuatan dirinya untuk bisa

\footnotetext{
${ }^{16}$ Fuad.

17 Yudan Hermawan and Yoyon Suryono, "Partisipasi Masyarakat Dalam Penyelenggaraan ProgramProgram Pusat Kegiatan Belajar Masyarakat Ngudi Kapinteran," JPPM (Jurnal Pendidikan Dan Pemberdayaan Masyarakat) 3, no. 1 (2016): 97-108.
} 
berkembang secara optimal. Pemerintah dengan semua aparat dan jajarannya perlu menampilkan diri sebagai pelayan yang cepat tanggap, cepat memberikan perhatian, tidak berbelit-belit, dan bukan minta dilayani. Masyarakat harus diposisikan sebagai focus pelayanan utama.

Bentuk keterlibatan pemerintah dalam pelaksanaan pendidikan berbasis masyarakat pada Madrasah Aliyah Al-Ma'arif Bilae Kabupaten Bone yaitu dengan memberikan ijin operasional pendirian lembaga. Dengan adanya ijin tersebut sehingga dijadikan dasar bagi pihak madrasah dalam melaksanakan program yang telah dibuat. Selain itu bentuk dukungan dari pihak madrasah adalah dengan melakukan bimbingan baik dari segi manajemen pembelajaran maupun tatakelola administrasi madrasah. Begitu pula dengan pengembangan kapasitas tenaga pendidiknya pihak pemerintah melaksanakan pelatihan salah satunya adalah pelatihan kurikulum 2013.

\section{Sarana dan Prasarana}

Sarana dan prasarana adalah segala sesuatu yang mendukung secara langsung terhadap kelancaran proses pembelajaran, misalnya media pembelajaran, alat-alat pelajaran, perlengkapan sekolah sedangkan prasarana meliputi jalan menuju sekolah, penerangan sekolah, kamar kecil dan lainnya. Sarana dan prasarana merupakan faktor pendukung dalam penerapan pendidikan berbasis masyarakat pada Madrasah Aliyah Al-Ma'arif Bilae Kabupaten Bone.

Sarana yang ada pada Madrasah Aliyah Al-Ma'arif Bilae Kabupaten Bone cukup mendukung dalam pelaksanaan proses pembelajaran hal ini terbukti dengan tersedianya gedung kelas sebagai tempat bagi siswa untuk belajar yang dilengkapi dengan media pembelajaran. Selain itu juga tersedia media pebelajaran lain sebagai pendukung pengembangan bakat siswa khususnya dalam kegiatan ekstra kurikuler yaitu alat-alat kesenian. Prasarana yang ada pada Madrasah Aliyah Al-Ma'arif Bilae Kabupaten Bone juga mendukung dalam pelaksanaan pembelajaran salah satu contohnya yaitu jarak antara sekolah dengan jalanan poros tidak terlalu jauh sehingga madrasah tersebut mudah dijangkau.

Selain faktor pendukung tersebut penerapan pendidikan berbasis masyarakat pada Madrasah Aliyah Al-Ma'arif Bilae Kabupaten Bone juga mengalami hambatan. Adapun yang menjadi penghambat dalam pelaksanaan pendidikan tersebut adalah Sistem perencanaan dan Keterbatasan anggaran.

\section{Perencanaan}

Perencanaan merupakan bagian yang tidak dapat dipisahkan dalam dunia pendidikan terlebih lagi pada perencanaan dalam dunia pendidikan. Tugas utama yang dilakukan oleh guru terkait dengan pendidikan adalah melakukan penjabaran dari rencana pembelajaran ke dalam silabus yang operasionalnya dapat rinci serta siap dijadikan pedoman dan skenario dalam pembelajaran. Perencanaan yang bermuara pada pelaksanaan pembelajaran, sedikitnya mencakup tiga kegiatan, yaitu identifikasi kebutuhan, perumusan kompetensi dasar, dan penyusunan program pembelajaran.

Terkait identifikasi kebutuhan, kebutuhan merupakan kesenjangan antara apa yang seharusnya dengan kondisi yang sebenarnya atau sesuatu yang harus dipenuhi untuk mencapai tujuan. Pada tahap ini melibatkan peserta didik untuk mengenali, menyatakan dan merumuskan kebutuhan belajar, sumbersumber yang tersedia dan hambatan yang mungkin dihadapi dalam kegiatan pembelajaran untuk memenuhi kebutuhan belajar. Pelibatan peserta didik perlu disesuaikan dengan tingkat kematangan dan kemampuan peserta didik, dalam pelaksanaannya peserta didik memberikan kepercayaan sepenuhnya kepada guru.

Identifikasi kompetensi, kompetensi merupakan sesuatu yang ingin dimiliki oleh peserta didik dan merupakan komponen utama yang harus dirumuskan dalam pembelajaran yang memiliki peran penting dan menentukan arah pembelajaran. Kompetensi yang jelas akan memberi petunjuk yang jelas pula terhadap materi yang harus dipelajari, penetapan metode dan media pembelajaran, serta memberi petunjuk terhadap penilaian. Oleh karena itu, setiap kompetensi harus merupakan perpaduan dari pengetahuan, keterampilan, nilai dan sikap yang direfleksikan dalam kebiasaan berpikir dan bertindak.

Penyusunan program pembelajaran, muaranya pada Rencana Pelaksanaan Pembelajaran, sebagai produk program pembelajaran jangka pendek yang mencakup komponen program kegiatan belajar dan proses pelaksanaan program. Komponen program mencakup kompetensi dasar, materi standar, metode dan teknik, media dan sumber belajar, waktu belajar dan daya dukung lainnya.

Melihat gambaran di atas dapat dikemukakan bahwa membuat perencanaan pembelajaran sangat menentukan terhadap prestasi belajar siswa, sebab dengan adanya program yang jelas dan terarah akan 
menjadi pedoman bagi guru untuk menentukan langkah-langkah atau strategi dalam mencapai tujuan pembelajaran, tanpa program yang jelas dan terarah maka guru tidak mempunyai pedoman yang jelas pula dalam mengajar, sehingga akan mempersulit tercapainya tujuan pembelajaran yang pada akhirnya akan berakibat prestasi belajar siswa menjadi kurang baik, maka guru sangat diharapkan untuk dapat membuat perencanaan pembelajaran dengan baik, seperti yang di ungkapkan bahwa keberhasilan perencanaan sangat menunjang keberhasilan kegiatan pengelolaan pembelajaran, dan sangat menentukan hasil belajar secara keseluruhan.

Akan tetapi, penerapan program tersebut membutuhkan keterlibatan guru secara aktif dalam mengelola prencanaan pembelajaran dengan harapan agar alur dari sebuah proses pembelajaran dapat berjalan dengan baik. Begitupula dengan perencanaan pendidikan berbasis masyarakat yang proses pelaksanaannya membutuhkan perencanaan yang matang karena konsep tersebut lahir dari masyarakat bukan dari pemerintah secara umum. Kenyataannya sekarang adalah perencanaan yang menitik beratkan pada keterlibatan masyarakat belum maksimal dilaksanakan, sehingga pihak madrasah mengelola sendiri proses perencanaan dengan tetap mengacu pada sistem pendidikan secara umum. Dengan tidak adanya konektifitas antara pihak madrasah dengan masyarakat sehingga penerapan pendidikan berbasis masyarakat secara utuh sulit tercapai. Hal inilah yang menjadi faktor penghambat penerapan pendidikan berbasis masyarakat pada Madrasah Aliyah Al-Ma'arif Bilae Kabupaten Bone.

Berdasarkan permasalahan tersebut dibutuhkan solusi yang epektif dalam mengatasinya, salah satu solusi yang penulis berikan adalah dengan memberikan penyadaran kepada masyarakat mengenai peranannya dalam pengembangan pendidikan bukan hanya sebatas penyediaan sarana dan prasarana. Namun yang lebih penting adalah keterlibatan mereka dalam pengembangan pembelajaran itu sendiri, sehingga masyarakat diharapkan terlibat langsung dalam penyusunan rencana strategia madrasah. Begitu pula dengan pihak madrasah harus memahami mengenai fungsi dari pendidikan berbasis masyarakat agar supaya mereka dapat membedakan pengembangan madrasah yang kaitannya dengan keterlibatan masyarakat serta pengembangan madrasah dengan keterlibatan pemerintah.

\section{Anggaran}

Pengembangan dari sebuah proses pembelajaran harus didukung oleh berbagai hal salah satunya adalah berkaitan dengan anggran. Pemerintah harus memahami bahwa masyarakat yang dilayani pada umumnya adalah masyarakat yang kurang mampu, baik dalam ilmu maupun ekonomi. Belajar untuk belajar bukan menjadi tujuan, tetapi belajar untuk hidup dalam arti bermata pencaharian yang layak. Untuk itu diperlukan modal sebagai modal dasar untuk menerapkan apa yang diyakininya dapat dijadikan sebagai sumber kehidupan dari apa yang sudah dipelajarinya. Pemerintah berperan sebagai penyedia dana yang dapat mendukung keseluruhan kegiatan pendidikan yang diperlukan oleh masyarakat.

Pemerintah telah hadir ditengah-tengah masyarakat untuk memberikan pembinaan pendidikan secara formal. Pembinaan yang dimaksud adalah dengan memberikan bantuan pendanaan kepada madrasah dengan tujuan proses pembelajaran berjalan dengan maksimal. Namun anggaran tersebut masih belum mencukupi mengingat kebutuhan madrasah cukup tinggi karena masih dalam proses pengembangan. Oleh karena itu, dibutuhkan campur tangan masyarakat dalam mengatasi permasalahan tersebut khususnya dari segi anggaran. Sehingga anggaran dari pemerintah dapat dialokasikan pada pengembangan madrasah dari sisi formalnya dan anggrana dari masyarakat dapat digunakan pada pengembangan nonformal.

Berdasarkan pada permasalahan tersebut maka dibutuhkan solusi kongkrit sehingga madrasah dalam melakukan proses pengembangan tidak terkendala dari segi anggaran. Untuk mengatasi hal ini penyadaran masyarakat tentang pentingnya pengembangan pendidikan sangat dibutuhkan terlebih pada pengembangan anggaran. Salah satu cara yang bisa dilakukan oleh pihak madrasah adalah menggali potensi masyarakat dalam hal ini adalah penghasilan dari masyarakat tersebut. Pendapatan utama masyarakat disekitar Madrasah Aliyah Al-Ma'arif Bilae Kabupaten Bone adalah petani, sehingga pihak madrasah harus mencoba membangun komunikasi dengan mereka dalam bentuk membangun kesepakatan agar masyarakat dapat memberikan sebagian pendapatannya dari bertani pada saat setelah panen. Proses pembayaran yang dimasud dapat berupa uang ataukah pada yg nominalnya sesuai dengan kesepakatan bersama. 


\section{SIMPULAN DAN SARAN}

\section{Simpulan}

Penerapan pendidikan berbasis masyarakat pada Madrasah Aliyah Al-Ma'arif Bilae Kabupaten Bone mengacu pada tiga hal yaitu, proses pendirian madrasah pada awalnya masyarakat tidak membebani pemerintah dalam penyediaan sarana dan prasarana. Merekalah yang berusaha secara gotong-royong menyediakan sarana dan prasarana tersebut. Usaha tersebut juga didukung oleh pihak yayasan yang memberikan kesempatan kepada masyarakat untuk berusaha dalam rangka pengembangan madrasah sehingga masyarakat merasa memiliki dan bertanggungjawab terhadapa keberadaan madrasah tersebut. Selain itu, dalam rangka menggali informasi mengenai pengembangan lembaga pendidikan masyarakat melakukan konsultasi keberbagai pihak yang telah berpengalaman dalam pengelolaan lembaga pendidikan.

Faktor pendukung dalam pelaksanaan pendidikan berbasis masyarakat pada Madrasah Aliyah AlMa'arif Bilae kabupaten Bone adalah dari masyarakat, pemerintah serta sarana dan prasarana. Masyarakat merasa bertanggung jawab mengenai keberadaan madrasah sehingga mereka memiliki peran dalam proses pendiriannya, begitu pula dengan pemerintah yang atas kuasanya mengeluarkan ijin operasional madrasah. Terkait dengan sarana dan prasarana yang ada cukup membantu dalam proses belajar mengajar. Adapun yang menjadi faktor penghambat adalah perencanaan dan anggaran. Perencanaan pembelajaran berbasis masyarakat pada Madrasah Aliyah Al-Ma'arif Bilae Kabupaten Bone belum maksimal salah satunya adalah belum adanya identifikasi kebutuhan. Masyarakat memposisikan dirinya hanya sebatas penyediaan sarana dan prasarana tidak masuk pada perencanaan pembelajaran terkhusus pada pengembangan kurikulum. Oleh karena itu, untuk mengatasi permasalah ini masyarakat dituntut untuk terlibat dalam pengelolaan madrasah selama tidak melanggar aturan yang ada. Begitu pula dari segi penganggaran pihak madrasah hanya berharap dari bantuan pemerintah sehingga masyarakat diharapkan berperan aktif untuk mencarikan solusi mengenai pengembangan anggaran pada Madrasah Aliyah Al-ma'arif Bilae kabupaten Bone.

\section{Saran}

Untuk pihak madrasah, masyarakat hendaknya diberikan ruang untuk berperan aktif dalam memberikan solusi mengenai pengembangan anggaran pada Madrasah Aliyah Al-ma'arif Bilae kabupaten Bone.

\section{DAFTAR PUSTAKA}

Fuad, Nurhattati. "Manajemen Pendidikan Berbasis Masyarakat: Konsep dan Strategi Implementasi." Jakarta: Raja Grafindo Persada, 2014.

Hasanuddin, Sultan. "Pembinaan Mahasiswa Prodi Pendidikan Agama Islam yang Aktif pada Organisasi Mahasiswa IAIN Bone.” Ekspose: Jurnal Penelitian Hukum dan Pendidikan 17, no. 1 (2019): 539-48.

Hermawan, Yudan, and Yoyon Suryono. "Partisipasi Masyarakat dalam Penyelenggaraan ProgramProgram Pusat Kegiatan Belajar Masyarakat Ngudi Kapinteran.” JPPM (Jurnal Pendidikan Dan Pemberdayaan Masyarakat) 3, no. 1 (2016): 97-108.

Hidayat, Rhamat. "Pendidikan Berbasis Masyarakat." Jurnal Attarbiya 1, no. 1 (2004): 184.

Indonesia, Presiden Republik. Undang-undang Republik Indonesia nomor 20 tahun 2003 tentang sistem pendidikan nasional, Pub. L. No. 20, 79 (2003).

Muliadi, Erlan. "Urgensi Pembelajaran Pendidikan Agama Islam Berbasis Multikultural di Sekolah." Jurnal Pendidikan Islam 1, no. 1 (2012): 55-68.

Riyanto, Yatim. Metodologi Penelitian Pendidikan Kualitatif dan Kuantitatif. Surabaya: Unesa university press, 2007.

Rochmawati, Ida. "Optimalisasi Peran Madrasah dalam Pengembangan Sistem Nilai Masyarakat." PEDAGOGIA: Jurnal Pendidikan 1, no. 2 (2012): 161-72.

Ruyadi, Yadi. "Model Pendidikan Karakter Berbasis Kearifan Budaya Lokal: Penelitian Terhadap Masyarakat Adat Kampung Benda Kerep, Cirebon, Provinsi Jawa Barat Untuk Pengembangan Pendidikan Karakter Di Sekolah." In Proceedings of The 4th International Conference on Teacher 
Education, 577-95, 2010.

Sihombing, Umberto. "Menuju Pendidikan Bermakna Melalui Pendidikan Berbasis Masyarakat." Jakarta: CV Multiguna, 2002.

Sudjana, Djudju. "Pendidikan Nonformal: Wawasan, Sejarah Perkembangan, Filsafat, Teori Pendukung, Asas." Bandung: Falah Production, 2004.

Sugiyono. Metode Penelitian Pendidikan:(Pendekatan Kuantitatif, Kualitatif dan $R \& D$ ). Alfabeta, 2008.

Suharto, Toto. Pendidikan Berbasis Masyarakat; Relasi Negara dan Masyarakat dalam Pendidikan. LKIS Pelangi Aksara, 2012. 